https://doi.org/10.31426/ijamsr.2018.1.9.913

International Journal of
I J A M S R

\title{
EVALUATION OF PUBLIC HIGH SCHOOL LIBRARIES
}

\author{
Ma. Gloria E. Liquido ${ }^{1}$, Camilo T. Fernandez ${ }^{2}$
}

Faculty, College of Education, Caraga State University, Butuan City, Philippines

Principal, Marist School, Marikina City, Philippines

magelqui@gmail.com

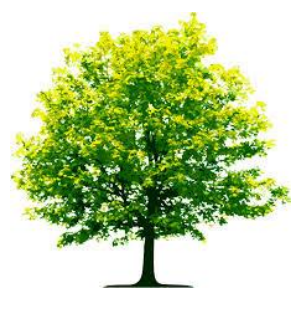

Keywords: $\quad$ Discrepancy

Evaluation Model; Standards for Philippine Libraries; public high school libraries

\begin{abstract}
A B S T R A C T
This study aimed to determine the level of adequacy of public high school libraries in Quezon City, Philippines. The 3 public school libraries were chosen as evaluands purposefully because it represented the library resources of performing public schools. The main data collection instrument was interviewed schedules. For appreciation, checklist, observation notes and secondary data were also used. In conclusion, Schools $A$ and $C$ maintained an acceptable level of adequacy based on the criteria set in the Standards for Philippine Libraries. School B, however, barely approached the same level of adequacy due to the sheer size of the student population that the library serves.
\end{abstract}

Citation: Ma. Gloria E. Liquido, Camilo T. Fernandez (2018). Evaluation Of Public High School Libraries. International Journal of Advanced Multidisciplinary Scientific Research (IJAMSR ) ISSN:2581-4281 Vol 1, Issue 9, November, 2018, \#Art.913, pp 21-35

\section{Introduction}

Libraries are viewed as part of the learning infrastructure of a school. As such, it is neither exempt nor spared from being evaluated. If key elements of schools like teachers' performances are subject to evaluation annually or as periodically prescribed, so are the library's services and resources.
Library standards are essentially the 'must-have tools' used to gauge effectiveness and adequacy of library services. Using these standards as the yardstick for evaluation, decisions on 'what and how' to improve on the library services can be made to attain quality and excellence in the library's operations. The Standard for Philippine Libraries: School Library and Media Centers, stipulated in Republic Acts 6966 and 9246 provides the context with which libraries in the country are gauged 


\section{International Journal of Advanced Multidisciplinary Scientific Research (IJAMSR) ISSN:2581-4281}

and evaluated. It has nine standards which are listed as follows:
a) Mission, Goals, and Objectives
b) Administration
c) Human Resources
d) Collection Management
e) Services and Utilization
f) Physical Facilities
g) Information Technology Facilities and Services
h) Financial Resources, and
i) Linkages and Networking

This evaluation covered only eight (8) standards, excluding standard 1 Mission, Goals and Objectives.

Notwithstanding the existence of the preceding standards, determining excellence in the operations of libraries is not set in stone. A study of the Utah State Library Division (2003) on the Standards for Utah Public Libraries, stated that "there is no magic formula for library excellence - many factors contribute to the quality of a public library. But regardless of the specific situation of a particular library, some basic prerequisites are needed. Standards are only part of a planning and evaluation cycle. They are guided on which to base the existing conditions and services. Standards provide the environment in which to define the library's mission, set goals and objectives, choose strategies for achieving objectives and provide the climate for evaluation. Excellence in library service results when services match community needs, interests, and priorities.

To add to the foregoing concern on excellence, the needs, interests and priorities of schools and its libraries are changing according to the demands of time. Consequently, "libraries have responded effectively to many changes over the years. Recently, changes related to new technologies and media have come to the forefront. As library users seek access to a greater variety of materials, as well as computers and internet, the question arises as to whether these needs begin to supersede traditional library services like the reference, circulation, and programming" (Library Research Service of Colorado Public Libraries, 2008). As the library services and the nature of access have evolved, all the more is seen the necessity of conducting evaluations along this aspect to justify timely learning, decisions, and actions for improvement, enhancement of library services and access. Bryan (2011) in his study of Collaborative Portfolio's Effect on Library Usage, stated that "library resources are expensive, and it is the library media specialist's responsibility to ensure that the use of the library's resources is maximized to support the School Strategic Plan (SSP)."

Concerning of library size or dimensions as prescribed by the standards, the debate whether bigger libraries are better libraries or that small library is inadequate needs to be considered. The necessity of constructing new buildings solely for library facilities as may be warranted by public funds of the school requires review. Stancil (2009) in his study, The Not-So-Big High School Library Why Build Big? , claims that "it seems some agencies and organizations make no recommendations for the construction of new high school libraries whatsoever and leave it up to the architects to decide. The result is a hoped-for 


\section{International Journal of Advanced Multidisciplinary Scientific Research (IJAMSR) ISSN:2581-4281}

bigger and perhaps 'better' library without knowing what better is. Perhaps it is time to take a fresh look at the 'Not So Big Library' to see if there are any lessons to be learned before going big. Bigger may not be better, in fact, unless student use, circulation, and instruction warrant it." Stancil offers an advice by suggesting that schools employ an assessment of quality before deciding to pay for the difference between the best and adequate library. Only then, he says, that schools could tell if the expense is worth the difference.

\section{Evaluation Questions}

1. Based on the standards prescribed by Philippine Libraries, how adequate are the library and media center resources in terms of the following:
a) features,
b) budget,
c) staff,
d) access and services,
e) physical facilities, and
f) linkages and networking?

2. What services need to be provided in addition to those already available?

\section{Significance of the Study}

Operating in the context of public service with an increasing demand for accountability and effectiveness, this evaluation of public high school libraries in Quezon City is significant since it assessed and identified discrepancies between the standards against the performance of each school library. Taking into account that these three (3) libraries are all public and stateowned, this study sought to compare and unveil the observable differences of each library in terms of its features, budget, staff, access and services, physical facilities, linkages and networking. The result is hoped to be useful for the administrators of the respective schools as baseline information for improvement, if not, the development of additional library programs and services to better support the infrastructures for teaching and learning.

\section{Scope and Delimitation}

This study covered only three (3) public high school libraries in Quezon City. Mainly, it aimed to assess and compare the present and existing features, budget, staff, access and services, physical facilities, linkages and networking, including services needed to be provided in addition to those already available as identified by each school librarian and staff.

\section{Sample}

The three (3) public high school libraries are the object or the evaluand. They were purposively hand-picked to best serve the design of the study, i.e. assessment and comparison of these three (3) public high school libraries, their commonalities and differences in their nature as being public or state-owned, as an entity, and in terms of the identified variables under library evaluation - its features, budget, staff, access and services, physical facilities, linkages and networking. 


\section{International Journal of Advanced Multidisciplinary Scientific Research (IJAMSR) ISSN:2581-4281}

School A was created by RA 3661 signed into law in 1964 by President Diosdado Macapagal. Its educational emphasis is on Science and Math learning based on a full scholarship with the end view of preparing its students for science-oriented careers. It has a population of about 930 students, with one (1) Head Licensed Librarian, three (3) Assistant Librarians, and one (1) staff.

School B is a school of the Department of Education (DepEd) with about 5,000 students, accommodated into two (2) shifts i.e. morning and afternoon shifts. Its library is headed by one (1) Librarian, a BS Library Science and Information graduate (not yet licensed), and employed under a contractual arrangement by the local government. The librarian is assisted by an overseer, a teaching faculty of the English department. Hence the library is virtually under the auspices of the English department.

School C functions primarily at the laboratory school of the college of education of a university. It serves as the basic education unit at the University. It has a total of 1,068 students from Kindergarten to Grade 2, Grades 36, and Grades 7-10. It has three (3) separate libraries for each grade cluster. It is managed by one (1) Head Licensed Librarian, with three (3) staff, two (2) of whom are marketing graduates with one (1) undergraduate in BS Library Science.

\section{Data Collection Instrument}

The main data collection instrument was a set of interview questions posed to the Librarians and the staff of the three (3) public high school libraries. Also, a checklist, observation notes, and secondary data were also used during the ocular visit.

\section{Procedure}

The team of evaluators sought permission to visit the three (3) public high school libraries through a letter which were personally delivered and received by the secretariats of the chosen schools. Upon the approval of the visit by the School Principal, the group set-off on November 6, 2015 for the conduct of the interview and observation/ocular visit guided with the prepared and approved portfolio for the study tour and the itinerary of the visit.

After the data collection activity, the data was analyzed and interpreted and a final report of the evaluation activity was generated and submitted.

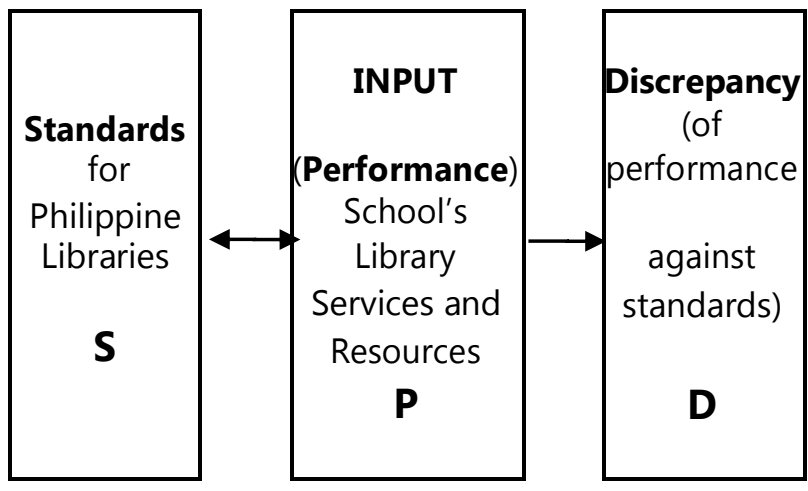

Figure 1 shows the connection linking the standards $(\mathrm{S})$ with the performance $(\mathrm{P})$ yielding discrepancy (D). In this evaluation, $\mathrm{S}$ stands for the Standards for Philippine Libraries, which was compared against the input (the school's library services and resources available) referred to as $\mathrm{P}$. The opposite-pointing arrow signifies the direct connection of $\mathrm{S}$ and $\mathrm{P}$ or vice versa. $\mathrm{S}$ specifies and directs the kinds of services, as well as the kinds and amount/number of resources the library must have. Virtually, it serves as the governing benchmark. P, on the other hand, is the input and the represents the 


\section{International Journal of Advanced Multidisciplinary Scientific Research (IJAMSR) ISSN:2581-4281}

extent of what has been complied with by the school in relation to S. "A program whose design has been judged adequate may nevertheless falter if it does not have the proper resources available when they are needed" (Steinmetz, 1977). D is the difference resulting from the $\mathrm{S}-\mathrm{P}$ comparison, yielding direct judgment of $\mathrm{P}$ regarding compliance with $\mathrm{S}$.

\section{Results\& Discussions}

\section{Adequacy of Library and Media Center Resources}

The result shows the identified performances of each school against the standards regarding features, budget, staff, and services, generated through an interview. The variables for standards are given indicators formulated as interview questions.

The Standards for Philippine Libraries: School Library and Media Centers was used in this specific evaluation question. The same standards were used for the comparison against the performance of the school library of schools A, B, and C as the object of evaluation. There were nine (9) indicators of standards, but only four (4) indicators for this particular evaluation question was used, namely, the standards for features, budget, staff and services. The same indicators were used as reference points for the interview schedules.

School A library featured comfortable amenities like it is air-conditioned and comfortable chairs and tables. It has the subscription to online databases accessible and separately situated in an internet/research room. It also has an area for off-class sessions and discussions. Its floor area was observed to be about five (5) standardsized classrooms, allowing for a free flow of traffic inside the library. In an interview, the Librarian states:
There are more students here in the library than in any place here in school. The students loved to study, do their class-related work. Also, we allow them to stay here for pleasure, say, if they want to sleep and take a nap, they can do it. We have an area over there.

Similarly, School B had notable features like eight (8) computer functional units with internet access which were primarily used for research and encoding. According to the Library In-charge, the school has about 1,500 collections under Filipiniana.

School C also has computer and internet facilities ready for use, although with fewer computer units compared to the other two schools. School $\mathrm{C}$ has established a strong linkage with alumni as evidenced by a series of donations annually received. All the three school libraries have functioned accordingly to its purpose when considering the provision of the usual services like book loan and borrowing books and other printed learning materials, use of internet access for research, and a venue for reading and studying class related works of the students.

Concerning the budget standards, of the three schools, only School A maintains a procedure where the head librarian presents a proposed budget to superiors for approval. Schools B and C, on the other hand, have budgets that are pre-allocated. School B's budget is allocated by law (General Appropriations Act) while School C's budget is a fixed annual amount determined by the school administration. Of these schools, only School A's library personnel have a say over how the budget is decided and spent. School B's and C's librarians are not empowered to make discretionary spending. In an interview, School B Library In-charge said: 


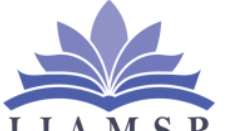

I J A M S R

\section{International Journal of}

Advanced Multidisciplinary Scientific Research (IJAMSR) ISSN:2581-4281

Though the library has $20 \%$ of the school's budget allocated, it was not at all implemented because it depends on the priority of the principal. Often, even if there are pending requests for library purchases and improvement, they remained as requests. I had initiated this library card for use by students, and they pay the minimal amount for this library card, and the money will be used for purchases of some library stuff, like ink for printing, spare parts for repair, only a minimal amount.

Concerning to the staff standards, library personnel qualifications for School B appears insufficient as well compared to the qualifications of the personnel from the other two schools. The lone librarian of School B functions as the audio- visual/computer technician as well.

Concerning to the library service standards, services and utilization appear to be approximately satisfactory in all three schools, suggesting an acceptable level of operational success, regarding book loan and use of computer and internet facilities. Exceptionally, School C had offered inter-library book loan by the Librarian herself; this was validated during the interview with her, as we quote:

When students come here and look for answers in their class assignments and projects, I always tell them, I may not know the answer, but I know where to find it, that is why I have this inter-library book loan.

A major difference, however, exists in the schedule with which library service is available among the schools. Schools A and C provide service to the school between 10 to 10.5 hours on the weekdays while School B provides the service for 12 hours. School B's service is thus surprising if not remarkable considering that only one librarian and another teaching faculty take charge of the library.

With the actual and observed performances of School A, School B and School C compared against Eight (8) Standards, i.e. administration, human resources in terms of student population ratio and qualifications, services and utilization, physical facilities, information technology facilities and services, financial resources, and linkages and networking, lifted from the Standards for Philippine Libraries: School Library and Media Centers of Professional Regulation Commission.

Table 1. Table of performances of schools against standards generated through face-to-face interview 
https://doi.org/10.31426/ijamsr.2018.1.9.913

\section{2 \\ I J A M S R \\ International Journal of Advanced Multidisciplinary Scientific Research (IJAMSR) ISSN:2581-4281}

\begin{tabular}{|c|c|c|c|}
\hline \multicolumn{2}{|c|}{ School A } & School B & School c \\
\hline \multicolumn{4}{|l|}{ Features } \\
\hline $\begin{array}{l}\text { 1. What } \\
\text { are the } \\
\text { notable } \\
\text { feature } \\
\text { s of the } \\
\text { library? }\end{array}$ & 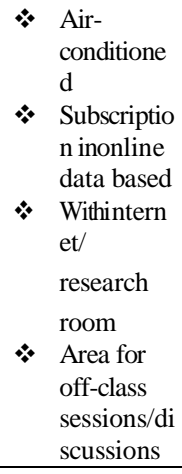 & $\begin{array}{l}\text { * units } \\
\text { offunctional } \\
\text { computer } \\
\text { usefor } \\
\text { internet } \\
\text { access/resea } \\
\text { rch } \\
\text { *,500 } \\
\text { collection } \\
\text { underFilipin } \\
\text { iana }\end{array}$ & $\begin{array}{l}\text { * Internet/compu } \\
\text { ter Facilities } \\
\text { * Strong/establis } \\
\text { hed linkage } \\
\text { with alumni as } \\
\text { evidenced } \\
\text { with series of } \\
\text { donations } \\
\text { annually } \\
\text { received both } \\
\text { local and } \\
\text { abroad }\end{array}$ \\
\hline $\begin{array}{l}\text { 2. By } \\
\text { what } \\
\text { system do } \\
\text { teacher } \\
\text { s and } \\
\text { student } \\
\text { s } \\
\text { access } \\
\text { the } \\
\text { library } \\
\text { resourc } \\
\text { es? }\end{array}$ & $\begin{array}{l}\text { *y } \\
\text { borrowing } \\
\text { books \& } \\
\text { other } \\
\text { printed } \\
\text { learning } \\
\text { materials } \\
\text { * Use of } \\
\text { internet } \\
\text { access \& } \\
\text { Wi-Fi } \\
\text { connectio } \\
\text { n }\end{array}$ & $\begin{array}{l}\text { By } \\
\text { borrowing } \\
\text { Books } \\
\text { Using } \\
\text { internet } \\
\text { facilities } \\
\text { A venue for } \\
\text { reading, } \\
\text { studying, \& } \\
\text { doing } \\
\text { classworks } \\
\text { Organization } \\
\text { like Library } \\
\text { Club, Book } \\
\text { Lovers Club } \\
\text { \& } \\
\text { Bookworm } \\
\text { that will } \\
\text { helpfacilitat } \\
\text { e fast } \\
\text { access of library } \\
\text { services } \\
\end{array}$ & $\begin{array}{l}\text { * Annual } \\
\text { orientation by } \\
\text { category,i.e. } \\
\text { K-2, Grade 3- } \\
\text { 6, Grade } 7-10 \\
\text { students \& } \\
\text { teachers on } \\
\text { library } \\
\text { services } \\
\text { Book Loan } \\
\text { Use of } \\
\text { internet } \\
\text { facilities } \\
\text { for research } \\
\text { and printing } \\
\text { E-Lib } \\
\text { subscription } \\
\text { Inter-Library } \\
\text { Book Loan }\end{array}$ \\
\hline \multicolumn{4}{|l|}{ BUDGET } \\
\hline $\begin{array}{l}3 . \text { Who } \\
\text { decides } \\
\text { the } \\
\text { budget for } \\
\text { the } \\
\text { library? }\end{array}$ & $\begin{array}{l}\text { Proposal - } \\
\text { based by } \\
\text { the Librarian }\end{array}$ & $\begin{array}{l}20 \% \text { of the } \\
\text { school's budget is } \\
\text { allocated to/for } \\
\text { library }\end{array}$ & $\begin{array}{l}\text { Fixed budget } \\
\text { allocation, } \\
\text { school's budget } \\
\text { is i.e. } \\
\text { Php120,000.00 } \\
\text { per } \\
\text { allocated to/for } \\
\text { from year } \\
\text { administration } \\
\text { library }\end{array}$ \\
\hline $\begin{array}{l}\text { 4. How is } \\
\text { it } \\
\text { decided? }\end{array}$ & $\begin{array}{l}\text { Proposal } \\
\text { subject for } \\
\text { approval } \\
\end{array}$ & $\begin{array}{l}\text { General } \\
\text { Appropriation } \\
\text { Act (GAA) }\end{array}$ & $\begin{array}{l}\text { Approval by } \\
\text { Administration }\end{array}$ \\
\hline $\begin{array}{l}\text { 5. Do } \\
\text { library }\end{array}$ & Yes & No & $\begin{array}{l}\text { The budget is } \\
\text { fixed/set }\end{array}$ \\
\hline
\end{tabular}

\begin{tabular}{|c|c|c|c|}
\hline $\begin{array}{l}\text { personnel } \\
\text { have a say } \\
\text { over how } \\
\text { the budget } \\
\text { is decided } \\
\text { or spent? }\end{array}$ & & & $\begin{array}{l}\text { annually for the } \\
\text { paymentonline } \\
\text { subscription,acqu } \\
\text { isition of books } \\
\text { (byfaculty } \\
\text { request), } \\
\text { maintenance and } \\
\text { among others. }\end{array}$ \\
\hline \multicolumn{4}{|l|}{ STAFF } \\
\hline $\begin{array}{l}6 . \text { What } \\
\text { are the } \\
\text { qualificati } \\
\text { ons of } \\
\text { Library } \\
\text { Personnel } \\
\text { ? }\end{array}$ & $\begin{array}{l}\text { Qualified, i.e. } \\
4 \text { Licensed } \\
\text { Librarians ( } 3 \\
\text { of which have } \\
\text { grandfather's } \\
\text { clause) \& } 2 \\
\text { staff with } \\
\text { Library-related } \\
\text { course }\end{array}$ & $\begin{array}{l}\text { BS in Library } \\
\text { Science \& } \\
\text { Information } \\
\text { (under License) } \\
\text { with an English } \\
\text { Teacher/Faculty } \\
\text { a Overseer }\end{array}$ & $\begin{array}{l}1 \text { Licensed } \\
\text { Librarian, } 3 \\
\text { staff for } 3 \\
\text { libraries , i.e. K- } \\
\text { 2, Grade 3-6 \& } \\
\text { Grade } 7-10 \text { for } \\
\text { 1,068 total } \\
\text { population of } \\
\text { students }\end{array}$ \\
\hline \multicolumn{4}{|c|}{ SERVICES } \\
\hline $\begin{array}{l}\text { 7. What } \\
\text { services } \\
\text { are } \\
\text { offered by } \\
\text { the } \\
\text { Library in } \\
\text { support of } \\
\text { instructio } \\
\mathrm{n} \text { ? }\end{array}$ & $\begin{array}{l}\text { Book } \\
\text { Lending/A } \\
\text { cquisition } \\
\text { Teachers } \\
\text { suggest } \\
\text { acquisition } \\
\& \text { updating }\end{array}$ & $\begin{array}{l}\text { Some teachers } \\
\text { borrowed books } \\
\text { as reflected in } \\
\text { their respective } \\
\text { library card }\end{array}$ & $\begin{array}{l}\text { Book Loan } \\
\text { Use of } \\
\text { internet } \\
\text { facilities for } \\
\text { research \& } \\
\text { printing } \\
\text { E-lib } \\
\text { subscription } \\
\text { Inter-library } \\
\text { book loan by } \\
\text { the Librarian } \\
\text { herself }\end{array}$ \\
\hline $\begin{array}{l}8 . \text { What } \\
\text { services } \\
\text { are } \\
\text { offered in } \\
\text { support of } \\
\text { student } \\
\text { learning? }\end{array}$ & $\begin{array}{l}\text { By } \\
\text { borrowing } \\
\text { books \& } \\
\text { other } \\
\text { printed } \\
\text { learning } \\
\text { materials } \\
\text { * Use of } \\
\text { internet \& } \\
\text { Wi-Fi } \\
\text { connection } \\
\text { Venue for } \\
\text { off-class } \\
\text { sessions/di } \\
\text { scussions }\end{array}$ & $\begin{array}{l}\text { By } \\
\text { borrowing } \\
\text { books } \\
\text { Using } \\
\text { internet } \\
\text { facilities } \\
\text { Avenue for } \\
\text { reading, } \\
\text { studying \& } \\
\text { doing class } \\
\text { works } \\
\text { Organization } \\
\text { like Library } \\
\text { Club, Book } \\
\text { Lovers Club } \\
\text { \& } \\
\text { Bookworm } \\
\text { that will help } \\
\text { facilitate fast } \\
\text { access of } \\
\text { library } \\
\text { services }\end{array}$ & $\begin{array}{l}\text { Book Loan } \\
\text { Use of } \\
\text { internet } \\
\text { facilities for } \\
\text { research \& } \\
\text { printing } \\
\text { E-lib } \\
\text { subscription } \\
\text { Inter-Library } \\
\text { Book Loan } \\
\text { by the } \\
\text { Librarian } \\
\text { herself }\end{array}$ \\
\hline
\end{tabular}




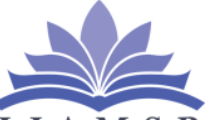

\section{International Journal of Advanced Multidisciplinary Scientific Research (IJAMSR) ISSN:2581-4281}

The first standard, which pertains to the administration of the library involves the provision of a program that integrates library and media center resources and services, its required professional leadership and staffing, and the periodic evaluation of beneficiaries such as faculty and students. Results indicate the presence of a unifying program in all three schools. However, professional staffing needs for School B need to be improved. Moreover, evaluation of personnel, services and resources are not conducted regularly in all three schools. While all three schools can report the conduct of some form of evaluative activity, the results are not used to inform on the library's services and resources for the purpose of subsequent improvement.

Results regarding the second standard, which pertains to human resources reveal a certain level of adequacy for schools $\mathrm{A}$ and $\mathrm{C}$ but shows a pronounced insufficient for school B regarding librarian-to-student ratio and personnel qualifications.

A survey of the third standard, which identifies the services required of a library shows an almost perfect performance by all three schools. School B, however, shows no coordination with the faculty for the purpose of promoting the effective use of the library. While all schools maintain a library schedule required from before classes start to after dismissal, school B goes beyond the expected keeping its doors open for close to 12 hours to accommodate the two shifts in classes.

Physical facilities for school B appear to be very limited with a single room that can accommodate about 50 students at most at a time. This is quite insufficient since it shows a bare $2 \%$ seating capacity. The same facilities for schools $\mathrm{A}$ and $\mathrm{C}$, on the other hand are adequate.
Regarding information technology facilities and services, results indicate the provision of access to the Internet. School B, however, does not have any internal communications service to coordinate its operations with the rest of the school.

Financial resources for all three schools appear to be adequate as revealed by interviews. Any summary observation of school bs library, however, will not fail to notice how in need of resources and supplies it is. In the interview, its lone librarian admitted that $20 \%$ of the general appropriations to the school is set aside for the library, but is subject to the discretionary authority of the principal to disburse based on the felt priorities of the school.

Linkages for schools $\mathrm{A}$ and $\mathrm{C}$ appear to be adequate, with the former's tie up with the Department of Science and Technology (DOST) and the latter's affiliation with the larger university. School B benefits from the occasional support and donations from the local government and concerned alumni.

Table 2. Comparison of Standards (Eight Standards) and Actual/Observed Performances per school 
https://doi.org/10.31426/ijamsr.2018.1.9.913

\section{2 \\ International Journal of Advanced Multidisciplinary Scientific Research (IJAMSR) ISSN:2581-4281}

\begin{tabular}{|c|c|c|c|}
\hline \multirow[b]{2}{*}{ STANDARDS } & \multicolumn{3}{|c|}{ ACTUAL AND OBSERVED } \\
\hline & $\begin{array}{c}\text { School } \\
\text { A } \\
\end{array}$ & $\begin{array}{c}\text { School } \\
\text { B }\end{array}$ & School C \\
\hline I. Administration & & & \\
\hline $\begin{array}{l}\text { 1. A unified program } \\
\text { integrating library and } \\
\text { audiovisual programs } \\
\text { under the leadership of } \\
\text { a qualified and } \\
\text { competent professional. }\end{array}$ & $\begin{array}{l}\text { Evident } \\
\text {, i.e. } \\
\text { there is } \\
\text { an } \\
\text { existin } \\
\text { g } \\
\text { progra } \\
\text { m } \\
\text { integrat } \\
\text { ing } \\
\text { library } \\
\text { and } \\
\text { audio- } \\
\text { visual } \\
\text { progra } \\
\text { ms } \\
\text { under a } \\
\text { leaders } \\
\text { hip of 1 } \\
\text { Head } \\
\text { Librari } \\
\text { an } \\
\text { (Licens } \\
\text { ed), } 3 \\
\text { Assista } \\
\text { nt } \\
\text { Librari } \\
\text { ans } \\
\text { (with } \\
\text { grandfa } \\
\text { ther's } \\
\text { clause } \\
\text { license) } \\
\text {, \& 1 } \\
\text { staff } \\
\end{array}$ & $\begin{array}{l}\text { There is } \\
\text { an } \\
\text { existing } \\
\text { progra } \\
\text { m } \\
\text { integrat } \\
\text { ing } \\
\text { library } \\
\text { and } \\
\text { audio- } \\
\text { visual } \\
\text { progra } \\
\text { ms, } \\
\text { howeve } \\
\text { r is } \\
\text { under a } \\
\text { Library } \\
\text { In- } \\
\text { charge } \\
\text { (under } \\
\text { licensed } \\
\text { ) } \\
\text { and a } \\
\text { Faculty } \\
\text { as } \\
\text { oversee } \\
\text { r of the } \\
\text { Library } \\
\text { In- } \\
\text { charge }\end{array}$ & $\begin{array}{l}\text { Evident, } \\
\text { i.e. } \\
\text { there is an } \\
\text { existing } \\
\text { program } \\
\text { integratin } \\
\mathrm{g} \\
\text { library } \\
\text { and } \\
\text { audio- } \\
\text { visual } \\
\text { programs } \\
\text { under } \\
\text { a } \\
\text { leadership } \\
\text { of } \\
1 \text { Head } \\
\text { Librarian } \\
\text { (Licensed } \\
\text { ) and } \\
3 \text { staff } \\
\text { posted } \\
\text { for } 3 \\
\text { libraries }\end{array}$ \\
\hline $\begin{array}{l}\text { 2. Where there are two } \\
\text { or more } \\
\text { professional } \\
\text { librarians, one is } \\
\text { appointed as the head to } \\
\text { oversee } \\
\text { the smooth } \\
\text { implementation of } \\
\text { services as well as the } \\
\text { supervision } \\
\text { personnel. }\end{array}$ & $\begin{array}{l}1 \text { Head } \\
\text { Librari } \\
\text { an, } 3 \\
\text { Assista } \\
\text { nt } \\
\text { Librari } \\
\text { ans } \\
\text { (All } \\
\text { License } \\
\text { d), \& 1 } \\
\text { staff }\end{array}$ & Missing & $\begin{array}{c}\checkmark \\
1 \text { Head } \\
\text { Librarian } \\
\text { (Licensed } \\
\text { ) and 1 } \\
\text { staff }\end{array}$ \\
\hline $\begin{array}{l}\text { 3. The school library } \\
\text { media center is }\end{array}$ & $\begin{array}{c}\text { Evaluat } \\
\text { ed }\end{array}$ & $\begin{array}{l}\text { Indirect } \\
\text { evaluati }\end{array}$ & $\begin{array}{c}\text { Indirect } \\
\text { evaluatio }\end{array}$ \\
\hline
\end{tabular}

\begin{tabular}{|c|c|c|c|}
\hline $\begin{array}{l}\text { regularly evaluated in } \\
\text { terms of its } \\
\text { services, personnel and } \\
\text { resources } \\
\text { by a. students, and }\end{array}$ & $\begin{array}{l}\text { annuall } \\
\mathrm{y} \text { as } \\
\text { part of } \\
\text { student } \\
\text { service } \\
\text { s by } \\
\text { student } \\
\text { s. }\end{array}$ & $\begin{array}{c}\text { on } \\
\text { of } \\
\text { library } \\
\text { resourc } \\
\text { es Only } \\
\text { for } \\
\text { clearan } \\
\text { ce } \\
\text { purpose } \\
\text { s of the } \\
\text { ones in- } \\
\text { charge. } \\
\text { Annuall } \\
\text { y done } \\
\text { by the } \\
\text { Library } \\
\text { In- } \\
\text { charge }\end{array}$ & $\begin{array}{l}\mathrm{n} \text { of } \\
\text { library } \\
\text { resources } \\
\text { and } \\
\text { services } \\
\text { Only for } \\
\text { Annual } \\
\text { Report } \\
\text { requireme } \\
\text { nt by the } \\
\text { Librarian }\end{array}$ \\
\hline b. faculty & None & None & None \\
\hline \multicolumn{4}{|l|}{ II. Human Resources } \\
\hline \multicolumn{4}{|l|}{ Student Population Ratio } \\
\hline $\begin{array}{l}\text { For an enrolment of } 500 \\
\text { or less, } 1 \text { full time } \\
\text { professional }+1 \\
\text { support staff }\end{array}$ & \multirow{3}{*}{$\begin{array}{l}920 \\
\text { student } \\
\text { s with } \\
1 \text { Head } \\
\text { Librari } \\
\text { an, } 3 \\
\text { Assista } \\
\text { nt } \\
\text { Librari } \\
\text { ans } \\
\text { (All } \\
\text { License } \\
\text { d), 1 } \\
\text { staff } \\
\text { (All } \\
\text { full } \\
\text { time) } \\
\mathbf{1 : 2 3 0}\end{array}$} & \multirow{3}{*}{$\begin{array}{l}5,000 \\
\text { total } \\
\text { students } \\
\text { populati } \\
\text { on } \\
\text { divided } \\
\text { into } \\
\text { shifts, } \\
\text { AM \& } \\
\text { PM } \\
\text { shifts, } \\
\mathbf{1 : 2 , 5 0 0} \\
\text { /shift }\end{array}$} & \multirow{3}{*}{$\begin{array}{l}\text { Total } \\
\text { students } \\
\text { for } \\
\text { Grades 7- } \\
10 \text { is } 390 \\
\text { with } 1 \\
\text { Librarian } \\
\text { \& } 1 \text { Staff } \\
\\
\quad \mathbf{1 : 3 9 0}\end{array}$} \\
\hline $\begin{array}{l}\text { For an enrolment of } 1000 \\
-1 \text { full time } \\
\text { professional head } \\
\text { librarian/media } \\
\text { specialist }+2 \text { support } \\
\text { staff }\end{array}$ & & & \\
\hline $\begin{array}{l}\text { For an enrolment of } 2,000 \\
-1 \\
\text { full time professional } \\
\text { head } \\
\text { librarian/media } \\
\text { specialist, } 2 \text { full } \\
\text { time librarian/media } \\
\text { specialist, } \\
\quad+4 \text { support staff }\end{array}$ & & & \\
\hline \multicolumn{4}{|l|}{ B. Qualifications } \\
\hline $\begin{array}{l}\text { Professional } \\
\text { Librarian - } \\
\text { BLS/BLIS graduate } \\
\text { orBSE/BSEEd } \\
\text { major or minor } \\
\text { inLibrary Science, or } \\
\text { - certifiedby Board } \\
\text { for Librarians } \\
\text { (orlicensed) }\end{array}$ & & $\begin{array}{l}\text { Library } \\
\text { In- } \\
\text { charge } \\
\text { is a } \\
\text { graduat } \\
\text { e of } \\
\text { Bachelo } \\
\mathrm{r} \text { of } \\
\text { Library } \\
\text { Science } \\
\text { and } \\
\text { Informa } \\
\text { tion }\end{array}$ & $\sqrt{ }$ \\
\hline
\end{tabular}


https://doi.org/10.31426/ijamsr.2018.1.9.913

\section{2 \\ I J A M S R \\ International Journal of Advanced Multidisciplinary Scientific Research (IJAMSR) ISSN:2581-4281}

\begin{tabular}{|c|c|c|c|}
\hline & & $\begin{array}{l}\text { (notlice } \\
\text { nsed) }\end{array}$ & \\
\hline $\begin{array}{l}\text { Library } \\
\text { Assistant/Clerk- } \\
\text { College/Secretarial } \\
\text { Graduate }\end{array}$ & & $\begin{array}{l}\text { No } \\
\text { Library } \\
\text { Assista } \\
\text { nt or } \\
\text { Clerk }\end{array}$ & $\sqrt{ }$ \\
\hline $\begin{array}{l}\text { Audio-Visual } \\
\text { Technician } \\
\text { 2-year course in } \\
\text { Electronics }\end{array}$ & & $\begin{array}{l}\text { Trained } \\
\text { and } \\
\text { Experie } \\
\text { nced } \\
\text { Technic } \\
\text { ian }\end{array}$ & $\begin{array}{l}\quad \checkmark \\
\text { Trained } \\
\text { Technicia } \\
\mathrm{n}\end{array}$ \\
\hline \multicolumn{4}{|c|}{ III.SERVICES\&UTILIZATION } \\
\hline $\begin{array}{l}\text { 1. The school library } \\
\text { media } \\
\text { center is open before } \\
\text { classes } \\
\text { to meet the need of } \\
\text { the } \\
\text { clientele and maximize the } \\
\text { use } \\
\text { of library resources, } \\
\text { facilities } \\
\text { and services. }\end{array}$ & $\begin{array}{l}\text { Library } \\
\text { Schedu } \\
\text { le } \\
\text { Mon - } \\
\text { Thurs } \\
\text { 7:30 } \\
\text { a.m.- } \\
\text { 5:30 } \\
\text { p.m. } \\
\text { Friday } \\
\text { 7:30a. } \\
\text { m.- } \\
\text { 5:00 } \\
\text { p.m. }\end{array}$ & $\begin{array}{l}\text { Library } \\
\text { Schedul } \\
\text { e } \\
\text { Mon- } \\
\text { Fri } \\
\text { 7:00 } \\
\text { a.m.- } \\
\text { 7:00 } \\
\text { pm }\end{array}$ & $\begin{array}{l}\text { Library } \\
\text { Schedule } \\
\text { Monday } \\
\text { 8:00 a.m. } \\
\text { 12:00nn } \\
\text { Tue-Fri } \\
\text { 7:00 a.m.- } \\
\text { 5:00p.m. }\end{array}$ \\
\hline $\begin{array}{l}\text { 2. The school library is } \\
\text { open } \\
\text { during classes to meet } \\
\text { the } \\
\text { need of the clientele } \\
\text { and } \\
\text { maximize the use of } \\
\text { library } \\
\text { resources, } \\
\text { services. }\end{array}$ & $\begin{array}{l}\text { Same } \\
\text { as } \\
\text { above } \\
\text { Library } \\
\text { Schedu } \\
\text { le }\end{array}$ & $\begin{array}{l}\text { Same } \\
\text { as } \\
\text { above } \\
\text { Library } \\
\text { Schedul } \\
\text { e }\end{array}$ & $\begin{array}{l}\quad \checkmark \\
\text { Same as } \\
\text { above } \\
\text { Library } \\
\text { Schedule }\end{array}$ \\
\hline $\begin{array}{l}\text { 3. The school library is } \\
\text { open afterclasses to } \\
\text { meet the need of the } \\
\text { clientele and } \\
\text { maximize the use of } \\
\text { library resources, } \\
\text { facilitiesand services }\end{array}$ & $\begin{array}{l}\text { Open } \\
\text { ONLY } \\
\text { as } \\
\text { schedul } \\
\text { ed } \\
\text { above }\end{array}$ & $\begin{array}{l}\quad \checkmark \\
\text { Open } \\
\text { ONLY } \\
\text { as } \\
\text { schedul } \\
\text { ed } \\
\text { above }\end{array}$ & $\begin{array}{l}\quad \checkmark \\
\text { Open } \\
\text { ONLY as } \\
\text { scheduled } \\
\text { above }\end{array}$ \\
\hline $\begin{array}{l}\text { 4. The } \\
\text { announcements of } \\
\text { acquisition and } \\
\text { other } \\
\text { promotional activities are } \\
\text { done periodically. }\end{array}$ & $\begin{array}{l}\text { Yes, } \\
\text { but not } \\
\text { periodi } \\
\text { cally } \\
\text { done }\end{array}$ & $\begin{array}{l}\text { Yes, } \\
\text { but } \\
\text { acquisit } \\
\text { ion } \\
\text { is } \\
\text { irregula }\end{array}$ & \\
\hline
\end{tabular}

\begin{tabular}{|c|c|c|}
\hline & $\begin{array}{l}\text { r. Since } \\
2012 \text { no } \\
\text { acquisit } \\
\text { ion } \\
\text { of } \\
\text { books } \\
\text { and no } \\
\text { promoti } \\
\text { onal } \\
\text { activitie } \\
\text { s or } \\
\text { record. } \\
\text { At } \\
\text { present, } \\
\text { only } \\
\text { donatio } \\
\text { ns from } \\
\text { alumni } \\
\text { are } \\
\text { receive } \\
\text { d, } \\
\text { periodic } \\
\text { ally }\end{array}$ & \\
\hline $\begin{array}{l}\text { 5. Coordination with the } \\
\text { faculty is } \\
\text { done to promote effective } \\
\text { use of } \\
\text { the school library media } \\
\text { center. }\end{array}$ & Missing & $\checkmark$ \\
\hline $\begin{array}{l}\text { Instruction on the } \\
\text { effective use } \\
\text { of the library media center } \\
\text { and } \\
\text { on various information } \\
\text { sources } \\
\text { is given to the students as } \\
\text { well } \\
\text { as to the faculty. }\end{array}$ & & $\checkmark$ \\
\hline $\begin{array}{l}\text { 7. The school library } \\
\text { media center } \\
\text { is available for use by } \\
\text { individual } \\
\text { students and by class } \\
\text { groups } \\
\text { throughout the school days. }\end{array}$ & $\checkmark$ & $\sqrt{ }$ \\
\hline $\begin{array}{l}\text { 8. Flexible scheduling } \\
\text { also exists } \\
\text { which enables the teacher } \\
\text { to } \\
\text { bring his/her class to the } \\
\text { library } \\
\text { at the time best suited } \\
\text { for the class } \\
\text { purpose of a c c }\end{array}$ & & $\checkmark$ \\
\hline
\end{tabular}


https://doi.org/10.31426/ijamsr.2018.1.9.913

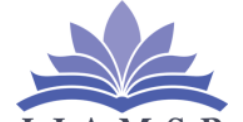

I J A M S R

\section{International Journal of} Advanced Multidisciplinary Scientific Research (IJAMSR) ISSN:2581-4281

\begin{tabular}{|c|c|c|c|}
\hline $\begin{array}{l}\text { supervised } \\
\text { research. }\end{array}$ & & & \\
\hline $\begin{array}{ll}\text { IV. } & \text { PHYSICAL } \\
& \text { FACILITIE } \\
& \text { S }\end{array}$ & & & \\
\hline $\begin{array}{l}\text { 1. The school library } \\
\text { media center } \\
\text { is housed in a barrier free, } \\
\text { and }\end{array}$ & & & $\checkmark$ \\
\hline $\begin{array}{l}\text { flexible facility that } \\
\text { canfacilitate a seating } \\
\text { capacity of } 10 \% \text { of } \\
\text { the total student } \\
\text { population. }\end{array}$ & & $\begin{array}{l}\text { Can } \\
\text { accom } \\
\text { modate } \\
\text { only to } \\
\text { at most } \\
50 \\
\text { students }\end{array}$ & $\checkmark$ \\
\hline $\begin{array}{l}\text { 2. The library has a } \\
\text { storage space for the } \\
\text { print collection, }\end{array}$ & $y$ & $\begin{array}{l}\text { Very } \\
\text { Limited }\end{array}$ & $\sqrt{ }$ \\
\hline reading area & d & $\begin{array}{l}\text { Very } \\
\text { Limited }\end{array}$ & $\checkmark$ \\
\hline work room, & 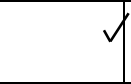 & $\begin{array}{l}\text { Very } \\
\text { Limited }\end{array}$ & $\sqrt{ }$ \\
\hline store room, & $\sqrt{ }$ & $\begin{array}{l}\text { Very } \\
\text { Limited }\end{array}$ & $\sqrt{ }$ \\
\hline $\begin{array}{l}\text { office for the } \\
\text { head librarian/media } \\
\text { center } \\
\text { coordinator, \& }\end{array}$ & $\downarrow$ & $\checkmark$ & $\checkmark$ \\
\hline $\begin{array}{l}\text { space for formal } \\
\text { library } \\
\text { instruction }\end{array}$ & 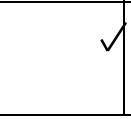 & $\sqrt{ }$ & $\checkmark$ \\
\hline \multicolumn{4}{|c|}{ V. Information Technology Facilities and Services } \\
\hline $\begin{array}{l}\text { 3. The school library } \\
\text { media center } \\
\text { have facilities for } \\
\text { information } \\
\text { technology and, }\end{array}$ & $y$ & $\begin{array}{l}\text { Comput } \\
\text { er units } \\
\text { are } \\
\text { functio } \\
\text { nal and } \\
\text { have } \\
\text { good } \\
\text { internet } \\
\text { connect } \\
\text { ion } \\
\end{array}$ & $\checkmark$ \\
\hline $\begin{array}{l}\text { communication } \\
\text { services }\end{array}$ & & $\begin{array}{l}\text { NO } \\
\text { Telepho } \\
\text { ne Line } \\
\end{array}$ & $\checkmark$ \\
\hline \multicolumn{4}{|c|}{ VI. FINANCIAL RESOURCES } \\
\hline $\begin{array}{l}\text { 4. The school has } \\
\text { adequate funds } \\
\text { for staffing, }\end{array}$ & & $\begin{array}{l}20 \% \text { of } \\
\text { the } \\
\text { GAA }\end{array}$ & $\checkmark$ \\
\hline $\begin{array}{l}\text { acquisition of } \\
\text { resources, and }\end{array}$ & & $\begin{array}{l}\text { Vout } \\
\text { subject }\end{array}$ & $\sqrt{ }$ \\
\hline $\begin{array}{l}\text { acquisition of } \\
\text { supplies in }\end{array}$ & & to & $\checkmark$ \\
\hline
\end{tabular}

\begin{tabular}{|c|c|c|c|}
\hline $\begin{array}{l}\text { support of the school } \\
\text { library media center } \\
\text { programs }\end{array}$ & & $\begin{array}{l}1 \\
\text { of the } \\
\text { School } \\
\text { Princip } \\
\text { al, and } \\
\text { dependi } \\
\text { ng on } \\
\text { the } \\
\text { prioritie } \\
\text { s of the } \\
\text { school }\end{array}$ & \\
\hline \multicolumn{4}{|c|}{ LINKAGES \& NETWORKING } \\
\hline $\begin{array}{l}\text { 5. The school library } \\
\text { media center } \\
\text { participated in resource } \\
\text { sharing } \\
\text { networks in order to } \\
\text { increase } \\
\text { the opportunities to } \\
\text { intensify the } \\
\text { collection and services. }\end{array}$ & $\begin{array}{l}\text { Thru } \\
\text { access } \\
\text { with } \\
\text { DOST }\end{array}$ & $\begin{array}{l}\text { Local } \\
\text { govern } \\
\text { ment } \\
\text { and } \\
\text { interest } \\
\text { ed } \\
\text { alumni }\end{array}$ & $\begin{array}{l}\quad \checkmark \\
\text { Thru } \\
\text { access } \\
\text { with its } \\
\text { Main } \\
\text { Library }\end{array}$ \\
\hline $\begin{array}{l}\text { 6. The school library } \\
\text { media center } \\
\text { has established } \\
\text { linkages with } \\
\text { other resource centers } \\
\text { in the } \\
\text { vicinity/community } \\
\quad \text { where } \\
\text { students can be referred } \\
\text { to for } \\
\text { research and } \\
\text { additional } \\
\text { sources of information. }\end{array}$ & $\begin{array}{l}\text { Thru } \\
\text { access } \\
\text { with } \\
\text { DOST }\end{array}$ & $\begin{array}{l}\text { Local } \\
\text { govern } \\
\text { ment } \\
\text { and } \\
\text { interest } \\
\text { ed } \\
\text { alumni }\end{array}$ & $\begin{array}{l}\text { Thru } \\
\text { access } \\
\text { with its } \\
\text { Main } \\
\text { Library }\end{array}$ \\
\hline
\end{tabular}

\section{Provision of Additional Services}

The result indicates that the libraries of the three (3) schools showed varied needs in terms of services that could be provided in addition to those already available. School A identified the need for an e-library and for an increase in the collection of books in the Sciences. School B, on the other hand, expressed the need for new collections of books and additional computer units for library use, which would be used particularly for 


\section{International Journal of Advanced Multidisciplinary Scientific Research (IJAMSR) ISSN:2581-4281}

research and internet access. School $\mathrm{C}$ stated the need for access to the university's main and college libraries for their Grades 7-10 students. Also, they declared the need for additional staff and a more spacious library.

Table 4. Services to be provided in addition to those already available

\begin{tabular}{|l|c|c|}
\hline School A & School B & School C \\
\hline E- & Additional & students be \\
Library & computerunits & allowed toaccess \\
More & for & the main library \\
books in & computerlaborat & and education \\
Science & ory & library \\
s than in & & More spacious \\
Humani & & library \\
ties & & Additional staff \\
& & \\
\hline
\end{tabular}

\section{Summary}

From the data gathered among the three schools, the following findings are presented.

A notable feature common among the three libraries is the facility to access the Internet for various research and information-gathering tasks. Schools $\mathrm{A}$ and $\mathrm{C}$ have better Internet access that School B, which provides only nominal access. Among the three, only School C provides remote library usage beyond any actual library visit. School C provides an E-lib subscription, which allows students to access the library on-line via local area network.
Of the three schools, only School A maintains a procedure where the head librarian presents a proposed budget to superiors for approval. Schools B and C, on the other hand, have budgets that are pre-allocated. School B's budget is allocated by law (General Appropriations Act) while School C's budget is a fixed annual amount determined by the school administration. Of these schools, only School A's library personnel have a say over how the budget is decided and spent. School B's and C's librarians are not empowered to make discretionary spending.

School A has the most number of licensed librarians with two other staff while school $\mathrm{C}$ has only one licensed librarian with three other staff who maintain two other libraries located in different parts of the campus. School B has no licensed librarian. The librarian is outsourced from the city government and is assisted by a teaching faculty from the English department.

All three schools invariably offer services where teachers and students can borrow books through a loan system managed by the library personnel. All schools offer Internet access to both students and teachers who conduct researches and information-gathering tasks for their respective classes. School $\mathrm{C}$ goes so far as to offer printing services for downloaded material. This is subject to a minimal fee, however. To aid student learning, the libraries of School A and School C allow the libraries to become venues for off-class sessions and discussions. School B further assists in facilitating activities of book-oriented clubs and organizations. 


\section{International Journal of Advanced Multidisciplinary Scientific Research (IJAMSR) ISSN:2581-4281}

Based on the Standards outlined in Standards for Philippine Libraries: School Library and Media Centers, all three schools maintain an integrated program whereby library and audiovisual resources are set under the supervision of competent personnel. School B, however, with only one nominal librarian assisted by a faculty member from the English department does not have a head librarian. School A conducts periodic formal evaluation conducted by the Student Services personnel. School C is partly evaluated as part of the annual report of the librarian while School B is evaluated by the librarian alone as part of his employment clearance.

Schools A and C by their limited and selective enrollment can achieve a librarian to student population ratio standard of 1:230 and 1:390 respectively. These figures are well within the set standard of 1:500. School $\mathrm{B}$, however, fails the standard with a ratio of 1:2500 at any given shift.

Library personnel qualifications for School B appears insufficient as well compared to the qualifications of the personnel from the other two schools. The lone librarian of School B functions as the audio-visual/computer technician as well.

Services and utilization appear to be approximately satisfactory in all three schools suggesting an acceptable level of operational success. A major difference, however, exists in the schedule with which library service is available among the schools. Schools A and C provide service to the school between 10 to 10.5 hours on the weekdays while School B provides the service for 12 hours. School bs service is thus surprising, if not remarkable considering that only one librarian and other teaching faculty take charge of the library.
Coordination with the faculty to promote the library's service is thus absent in School B while this is not so with the other two schools. This is done through library instruction which is conducted at least once a year for Schools A and C.

The physical facilities of Schools $\mathrm{A}$ and $\mathrm{C}$ are observably adequate while those of School B are very limited. There are a sufficient number of tables and chairs for individuals as well as groups in Schools A and C. School B, has very limited facilities in this respect.

While all three schools provide a functional and reliable internet connection for online research, School B does not even have a veritable telephone connection.

Financial resources are adequate for Schools A and C. This fact is manifested by the availability of new acquisitions displayed prominently on the shelves. School B however, despite the $20 \%$ allocation in the General Appropriations appears not to show any benefit from the funding. Most new acquisitions in School B come from donations through linkages with the local government and some generous alumni.

Linkages and networking that are intended to increase the opportunities to intensify the library's collection and services exist in all three schools. School A benefits from linkages with the Department of Science and Technology (DOST) and School C shares resources with the University's main library. School B, however, relies on the generosity of concerned alumni and local government offices which can only be described as spotty and trickling at best.

When queried as to whether other services need to be 


\section{International Journal of Advanced Multidisciplinary Scientific Research (IJAMSR) ISSN:2581-4281}

provided to better serve the library functions, all three schools responded positively. School A wishes for more resources in their E-library, which is a store of digitized database resources available for download. It also hopes to acquire more books that deal with the Sciences and less of those that deal in the humanities. School B wishes for more collections and additional computer units. School $\mathrm{C}$ wishes that their students are able to freely access the University's bigger libraries. It also hopes to augment their current complement of library personnel to provide better services in all three locations of their library.

\section{Conclusion}

Based on the foregoing summary, Schools A and C maintains an acceptable level of adequacy based on the criteria set in the Standards for Philippine Libraries: School Library and Media Centers. School B, however, barely approaches the same level of adequacy due to the sheer size of the student population that the library serves. In addition, for School B, the lack of qualified personnel to assist in the delivery of services places a huge stress on the library personnel to maintain the quality of service that is required by a library.

\section{Recommendations}

While all three schools displayed varying levels of adequacy in terms of services and resources, much can still be made in the way of improvement. The following recommendations are proposed given the findings of the study.

Based on the results of this study, it is recommended that regular and periodic evaluations of the libraries be conducted to constantly monitor the delivery of services and the adequacy of resources that are needed for the effective delivery of these services. This is supported by the finding that regular evaluation by both students and faculty appears to be partial, if not totally, absent from all three libraries surveyed. The conduct of such evaluations will provide the necessary information to the library personnel to strengthen the weak areas of their services and to properly direct the course of programs specific to their operations. Inputs relating to the kinds of books that are needed, subscription to online databases or the design of the library ambiance can be gathered from the school community and be made as part of the rationale for eventual planning.

It is further recommended that efforts be made to provide the necessary staffing for all three libraries. While School A shows staffing conditions which may be considered well above the required standard, Schools B and $\mathrm{C}$ exhibit the need to provide for adequate amount human resources to better serve the school community. School C, which presents a librarian to student ratio of 1:390 (considering high school students only) manages three libraries (two of the elements) at three different locations on the campus. This stretches manpower requirements, even if three library staff are available for deployment. School B, which operates for 12 straight hours due to the two shifts of classes has only one available librarian. Given more than 2,000 students at any given shift, achieving any kind of optimum library operation becomes impossible to, even if a teaching faculty is assigned to assist the librarian. Further, given that more teaching faculty may be assigned to assist the librarian at School B, these assistants need requisite training if they are to be of any help to critical library operations like cataloging and classifying materials. 
Lastly, greater gains will be made in bridging gaps in the delivery of library services by providing for increased funding and making sure these funds find their way into areas of library operations where they are needed most. Areas of library operations like an acquisition of books and other key materials can be made more substantial if funding is available. While it can be argued that the funding for all of these schools are subject to the checks and restraints of public money, a review of how these funds eventually influence the effectivity of the library's service to the school should be made to help the flow of funding find its way to the most critical areas.

\section{References}

1) Bryan, Valerie (2011). Collaborative Portfolio's Effect on Library Usage www.ebscohost.com

2) Library Research Service of Colorado Public Librararies (2008). www.ebscohost.com

3) Madaus, George F. et al (1983). Evaluation Models Viewpoints on Educational and Human Services

4) Evaluation. Kluwer-Nijhoff Publishing. Boston The Hague Dordrecht Lancaster Provus, Malcolm (1969).

5) The Discrepancy Model: An Approach to Local Program Improvement and Development.

6) The Board of Public Education. School District of Pittsburgh, Pennsylvania Stancil, George Ira III (2009).

7) The Not So Big High School Library...why build Big? www.ebscohost.com

8) Standards for Utah Public Libraries by Utah State Library Division (2003) www.ebscohost.com

9) Standards for Philippine Libraries: School Library and Media Centers 